BENTHAM OPEN
CrossMark
Content list available at: www.benthamopen.com/TODENTJ/
DOI: $10.2174 / 1874210601610010139$

\title{
Microscopic Study of Surface Microtopographic Characteristics of Dental Implants
}

\author{
M. Sezin ${ }^{1, *}$, L. Croharé ${ }^{2}$ and J.C. Ibañez ${ }^{3, *}$ \\ ${ }^{I}$ Faculty of Dentistry, National University of Cordoba, Argentina \\ ${ }^{2}$ Laboratory for Microscopy and Image Processing, Biology Dental Area, Faculty of Dentistry, National University of \\ Cordoba, Argentina \\ ${ }^{3}$ Faculty of Medicine, Catholic University of Cordoba, Argentina
}

Received: December 26, 2014

Revised: December 28, 2015

Accepted: December 30, 2015

\begin{abstract}
:
Objective:

To determine and compare the micro topographic characteristics of dental implants submitted to different surface treatments, using scanning electron microscopy (SEM).

\section{Materials and Methods:}

Implants were divided into 7 groups of 3 specimens each, according to the surface treatment used: group 1: Osseotite, BIOMET 3i; group 2: SLA surface, Institut Straumann AG; group 3: Oxalife surface, Tree-Oss implant; group 4: B\&W implant surface; group 5: Q-implant surface; group 6: ML implant surface; group 7: RBM surface, Rosterdent implant. The surfaces were examined under SEM (Carl Zeiss FE-SEM-SIGMA). Image Proplus software was used to determine the number and mean diameter of pores per area unit (mm). The data obtained were analyzed with the Mann-Whitney test. A confocal laser microscope (LEXT-OLS4100 Olympus) was used to conduct the comparative study of surface roughness (Ra). Data were analyzed using Tukey's HSD test.
\end{abstract}

Results:

The largest average pore diameter calculated in microns was found in group $5(3.45 \mu \mathrm{m}+/-1.91)$ while the smallest in group 7 $(1.47 \mu \mathrm{m}+/-1.29)$. Significant differences were observed among each one of the groups studied $(\mathrm{p}<0.05)$. The largest number of pores $/ \mathrm{mm}^{2}$ was found in group 2 (229343) and the smallest number in group 4 (10937). Group 2 showed significant differences regarding the other groups $(\mathrm{p}<0.05)$. The greatest roughness $(\mathrm{Ra})$ was observed in group $2(0.975 \mu \mathrm{m}+/-0.115)$ and the smallest in group $4(0.304 \mu \mathrm{m}+/-0.063)$. Group 2 was significantly different from the other groups $(\mathrm{p}<0.05)$.

\section{Conclusion:}

The micro topography observed in the different groups presented dissimilar and specific features, depending on the chemical treatment used for the surfaces..

Keywords: Dental implants, Micro topography, Osseointegration, Surface treatment, Titanium.

\section{INTRODUCTION}

In 1981, Albrektsson T et al. reported on a series of requirements that should be taken into account to achieve implant osseointegration: biocompatibility, implant design, surface conditions, state of the host site, surgical technique

\footnotetext{
* Address correspondence to these authors at the Faculty of Dentistry, National University of Cordoba, Argentina; Tel: +54 351 4815754; E-mail: mariosezin@hotmail.com and Faculty of Medicine, Catholic University of Cordoba, Argentina; Tel: +54 351 4680156; E-mail: dribanez@ibaimplantes.com
} 
applied, and loading conditions after placement [1]. In addition, primary stability of the implant, implant surface, geometry of the butress/pillar junction, and pillar/implant connection contribute to guarantee the preservation and permanence of implant-supported esthetic restorations.

The surface is a decisive factor in order to achieve and keep implant osseointegration and esthetic results; therefore, it is of paramount importance to select an implant surface designed to favor osseointegration, to preserve the crest bone and to offer a good level of protection against the development of peri-implantitis [2].

The major advances in the field of implantology are directly related to topographic and chemical changes on the surfaces of titanium implants. The effect of surface modifications by various treatments and the response of tissues to reduce the time necessary for osseointegration, to increase the initial biomechanical anchorage and to favor bone formation are improvements achieved through microstructural changes on the implant surfaces. Surface topography plays an increasingly important role in the complex process of early healing as well as in the changes in surface chemistry, being the presence of layers of calcium phosphate which produce and favor contact osteogenesis process [3] an example of these variations.

The different microtextured topographies promote initial healing due to the possibility of keeping blood fibrin during the critical stage of osteogenic cells migration around the implant [4]. Applying surface treatments to increase surface roughness of dental implants shows that implant osseointegration in the short and medium term is favored by a micro-roughened surface.

According to several experimental studies [3, $5-8]$ this improvement seems to be associated to the existence of microroughness of the implant surface, which favors cell adhesion and leads to a greater cell differentiation and greater osteoblast expression. This effect results in a rapid regeneration and in better quality of the osseous tissue. An implant with a complex surface microtopography is essential not only for the formation of contact osteogenesis but also for the adhesion of the bone matrix to the surface. These phenomena show the importance and influence that microtopography of the implant surface has on early healing and on the optimization of biological responses during the healing process.

Titanium is considered the material of choice to make dental implants. It has excellent resistance to corrosion and does not cause adverse hypersensitivity reactions, allergy or immune response. Its excellent biocompatibility is based on its mechanical properties mainly due to the spontaneous formation of a thin film of titanium oxide which provides natural protection against degradation attacks.

Topographic modification of titanium surfaces has been the object of investigation to improve osseointegration, so that it may directly affect cell adhesion, proliferation and differentiation produced during this process. Dental implants with various treatments on their surfaces are commercialized at present, but the literature shows contradictory results about the findings obtained. It is well known that topography, its roughness and chemical composition play a role in the long-term success of implant stability as well as in the reduction of healing time and prosthetic activation of implants.

Various surface treatments have been developed for dental implants. Osseotite surface from Biomet $3 \mathrm{i}$ implant is obtained with a double-acid etching as well as with a discrete calcium phosphate nanocrystalline deposition. Its topography includes 1-3 micro-roughness superimposed onto a slightly rough surface [2]. SLA surface of Straumann implants is obtained by sandblasting in order to get a macrostructure. This process is followed by double- acid etching with sulphuric and hydrochloric acids to get micropores. Oxalife surface from Tree-Oss implants is obtained through three procedures: sandblasting, for macro roughness, acid etching for micro roughness, and thermal treatment for an increased layer of titanium oxide implant. B\&amp;W implants are submitted to double-acid etching, a mixture of nitric acid and hydrochloric acid, at temperature. Specific treatment for Q-implant surfaces is based on the projection of particles followed by selective acid etching. ML implant surface is obtained by sandblasting, a process which consists in the projection of particles at high speed, acid-etching, and the formation of a homogeneous oxide layer of considerable thickness. RBM surface (Resorbable Blast Media) of Rosterdent implants is modified with biocompatible materials, such as calcium phosphate ceramics.

Therefore, the reasons stated to promote implants with surface modifications are that they 1) offer greater bone/ implant mechanic stability immediately after placement due to their larger contact area; 2) provide a surface configuration that adequately retains the blood clot; and 3) encourage the bone healing process [9]. The objective of this paper is to determine and compare the micro topographic characteristics of dental implants submitted to different surface treatments, by using a Scanning Electron Microscope (SEM) [10 - 12] . 


\section{MATERIALS AND METHODS}

Seven groups were considered according to their surface and structural characteristics: group 1: Osseotite implant, BIOMET 3i Implant Innovations, Palm Beach Gardens Fl, USA $(n=3)$, group 2: Straumann implant SLA, Institut Straumann AG, Waldenburg, Switzerland $(n=3)$, group 3: Tree-Oss implant, Buenos Aires, Argentina $(n=3)$, group 4: B\&amp;W implant, CABA, Argentina $(n=3)$, group 5: Q-implant, Buenos Aires, Argentina ( $n=3)$, group 6: $M L$ implant, Buenos Aires, Argentina ( $\mathrm{n}=3)$ and group 7: Rosterdent implant, Buenos Aires, Argentina ( $\mathrm{n}=3)$. The implant surfaces in each group were visualized with SEM (FE-SEM SIGMA Carl Zeiss trademark) to determine the diameter of the pores. Observations were made in the Laboratory of Electron Microscopy and X-ray Analysis (LAMARX), located in the Instituto de Física Enrique Gaviola (IFEG-CONICET). The visualization of the surface was performed at three sections, coronal, middle and apical sections in each one of the implants of the corresponding groups. The samples were placed on carbon discs for fixation and then inside the microscope chamber under vacuum conditions. When a vacuum value in the order of $5 \times 10^{-5}$ mbar was reached, high voltage was turned on and the images observed (Fig. 1).
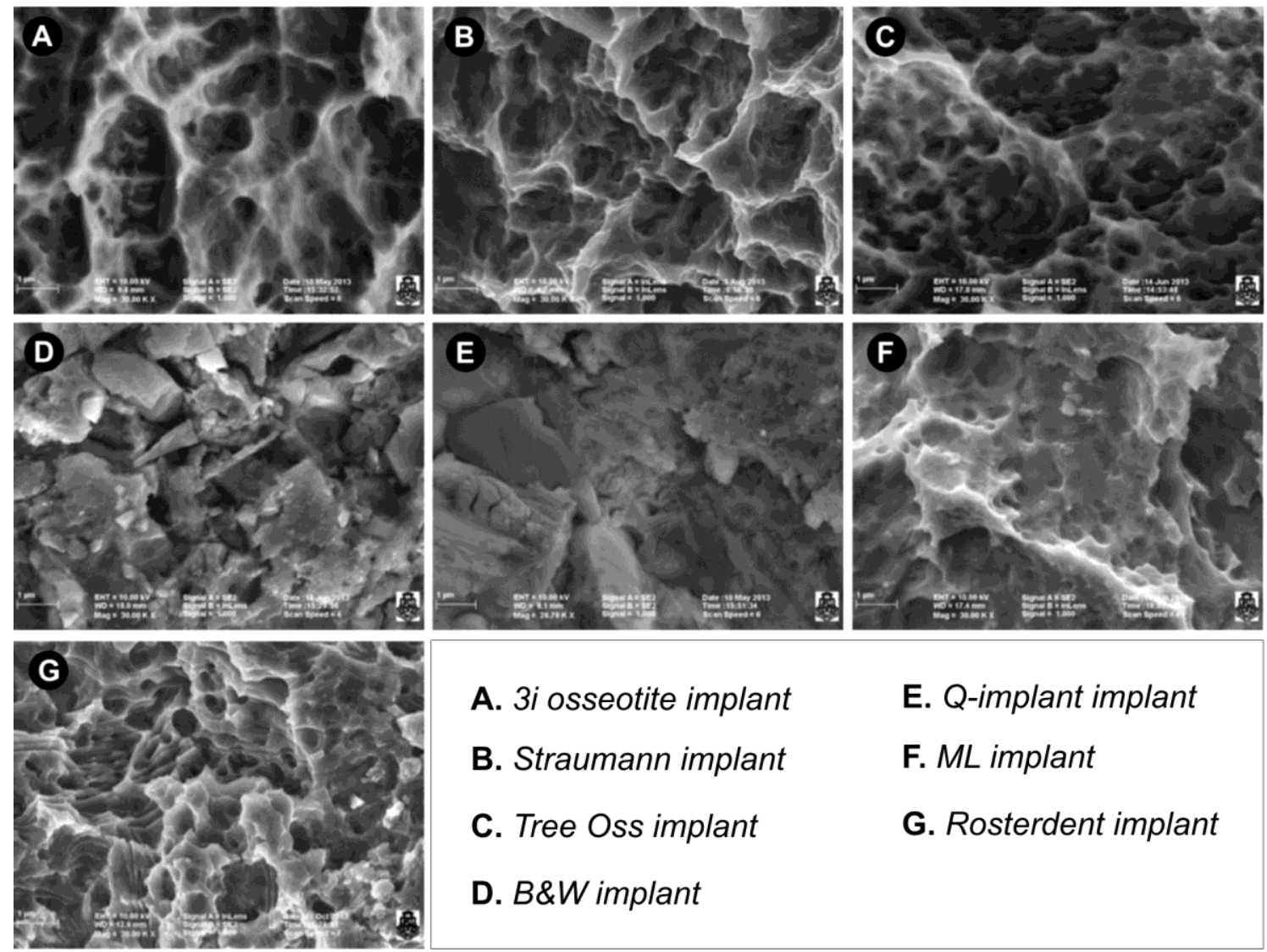
A. 3i osseotite implant
B. Straumann implant
C. Tree Oss implant
D. B\&W implant

\section{E. Q-implant implant \\ F. ML implant \\ G. Rosterdent implant}

Fig. (1). Surface implants of seven experimental groups. (A) Osseotite surface from BIOMET 3i osseotite surface implants. The surface treated with double acid-etching showing two-level topography with the presence of well-defined pores of different diameters. (B) Straumann SLA implant surface. Porous structures with smaller pores inside (fractal geometry) are observed. The smaller pores have the same structural shape as the larger pores. (C) Tree-Oss implant surface. Pores of various sizes presenting a uniform, rounded shape and great density per surface unit are observed. (D) B\&W Implant surface. Irregular particles of various sizes adhered to the surface are visualized. Large splinter-like particles and small rounded particles are observed. Measurements were made in the gaps found between the particles. (E) Q-implant surface showing squamous surfaces with facets parallel to each other. The interstices between the scales or lamellae are considered pores. (F) ML implant surface with concavities and porous formations with well-defined borders. (G) Rosterdent implant surface with pores localized in different scale-like strata.

To measure the diameter and number of pores, Image Pro-plus software was used; the pores were circumscribed to calculate the corresponding area, to obtain their average diameter and to quantify the number of pores per area unit. Pores presenting a diameter less than $1 \mu \mathrm{m}$ were excluded and undetermined structures observed on the images of each group were discarded (Fig. 2A) 
In order to do a comparative study of roughness, the arithmetic mean roughness measured in micrometers (Ra) was considered as a descriptive value, and a confocal laser microscope was used. This microscope has LEXT-OLS4100 Olympus software which allows for mapping on 12 points of each sample (Fig. 2B)
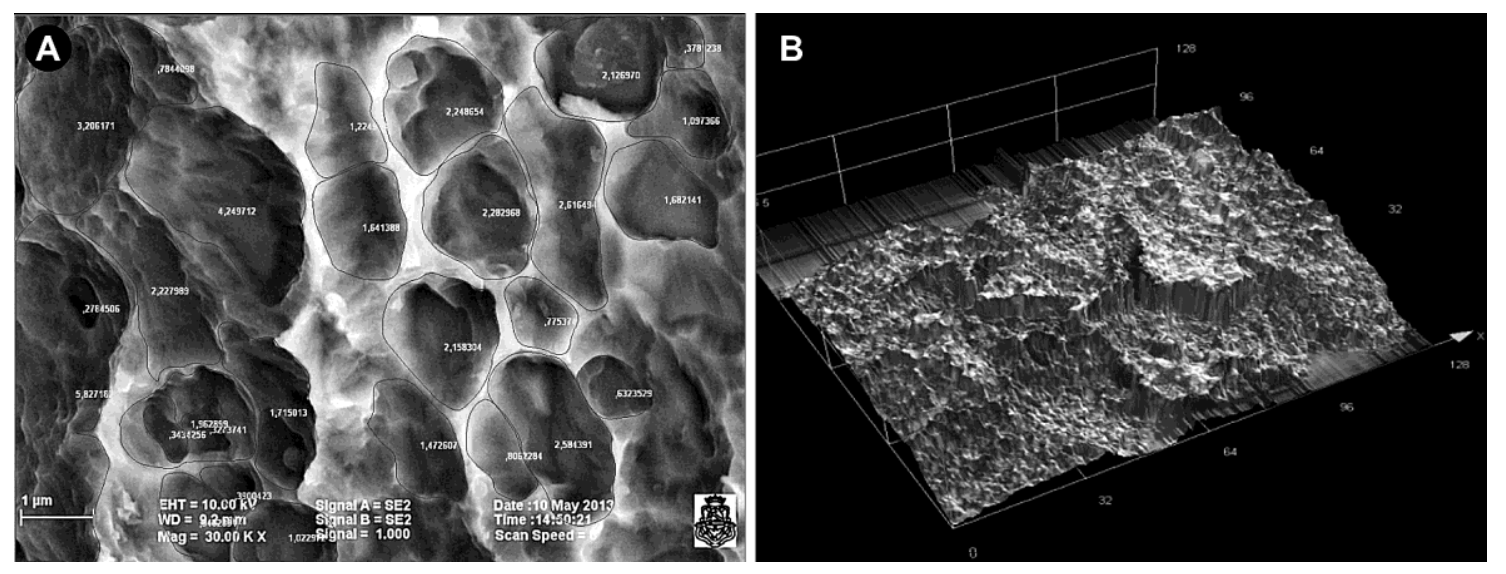

Fig. (2). (A) Microphotography of Osseotite surface of BIOMET $3 i$ implant. Example of the application of Image Proplus software to measure the diameter and number of pores. (B). Microphotography of Straumann SLA implant surface. Example of the application of LEXT-OLS4100 Olympus software for comparative study of roughness.

\section{Statistical Analaysis}

The data obtained on the diameter and number of pores were described by average values and interquartile ranges and/or standard deviation depending on the distribution of the sample data, and analyzed by Mann-Whitney test with SPSS 11.5 Windows program. The information on arithmetic mean roughness (Ra) thus obtained was submitted to the Tukey HSD Test.

\section{RESULTS}

\section{Pore Diameter}

According to the dimension of the pores, groups 1, 3, and 7 presented the lowest values, with no significant differences between them ( $p>0.05)$. When comparing group 4 and group 2 , it was found that there were no significant differences between them $(\mathrm{p}=0.088)$. Group 5 had the largest pores, thus showing significant differences with the other groups. $(p<0.05)$. Significant differences were found between groups 6 and $5(p=0.024)$ (Table 1).

Table 1. Statistical comparison of pore diameters.

\begin{tabular}{|c|c|c|c|c|c|}
\hline Implant & Mean & St. Dev. & Median & Min. & Max. \\
\hline BIOMET $3 \mathrm{i}$ & 1.81 & 0.61 & 1.74 & 0.94 & 3.65 \\
\hline Straumann & 2.52 & 1.11 & 2.28 & 1.02 & 6.70 \\
\hline Tree-Oss & 1.84 & 0.69 & 1.73 & 1.00 & 4.43 \\
\hline Rosterdent & 1.61 & 0.41 & 1.55 & 1.01 & 2.90 \\
\hline B\&W & 2.43 & 1.50 & 2.03 & 1.01 & 10.35 \\
\hline ML & 3.01 & 1.67 & 2.53 & 1.01 & 8.71 \\
\hline Q-Implant & 3.45 & 1.90 & 3.19 & 1.08 & 12.63 \\
\hline
\end{tabular}

\section{Number of Pores}

The largest number of pores was found in group 2 (229343 pores $\left./ \mathrm{mm}^{2}\right)$, followed by group $7\left(202362 \mathrm{pores} / \mathrm{mm}^{2}\right)$, group $1\left(167028\right.$ pores $\left./ \mathrm{mm}^{2}\right)$, group $3\left(120741\right.$ pores $\left./ \mathrm{mm}^{2}\right)$, group $6\left(42767\right.$ pores $\left./ \mathrm{mm}^{2}\right)$, group $5\left(22843\right.$ pores $\left./ \mathrm{mm}{ }^{2}\right)$ and group 4 (10937 pores $\left./ \mathrm{mm}^{2}\right)$. Fig. (3) shows the data distribution for each group.

Group 2 showed significant differences in relation to the other groups $(p<0.05)$. No significant differences were found between Groups 1 and $7(p=0.056)$; however, there were significant differences when these groups were 
compared with the remaining groups $(\mathrm{p}<0.05)$. Groups $3,6,5$, and 4 showed fewer pores $/ \mathrm{mm}^{2}$, with significant differences between them and between the other groups analyzed $(\mathrm{p}<0.05)$.

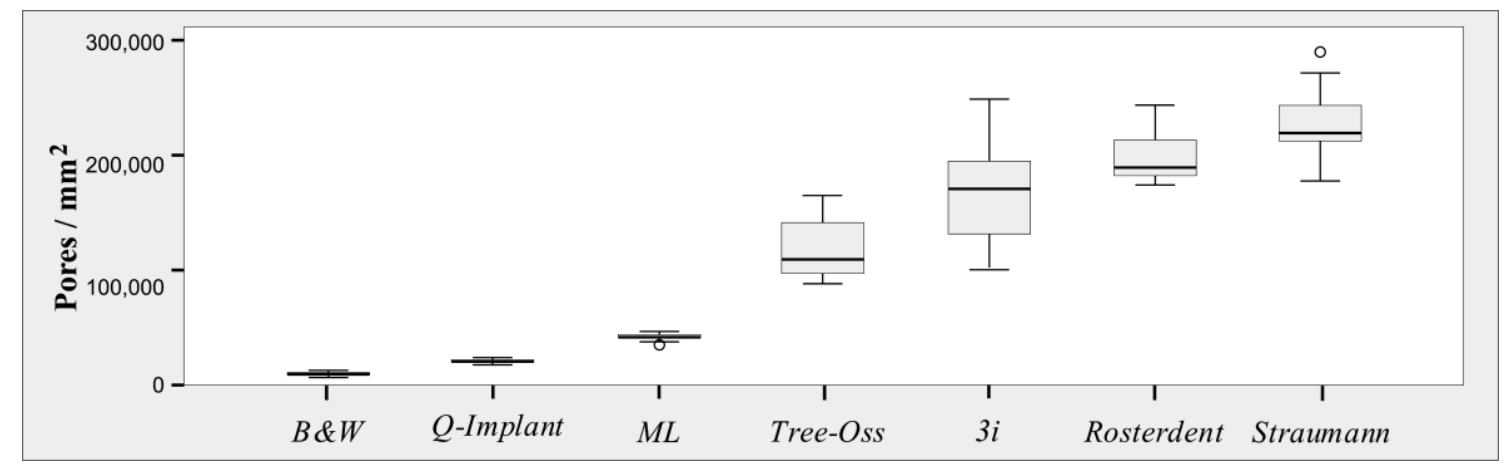

Fig. (3). Boxplot of values for number of pores according to trademarks studied.

\section{Arthimatic Mean Roughness (Ra)}

The greatest Roughness $(\mathrm{Ra})$, measured in micrometers, was found in group $2(0.975 \mu \mathrm{m}+/-0.115)$, followed by group $6,(0.475 \mu \mathrm{m}+/-0.081)$, group $3(0.379 \mu \mathrm{m}+/-0.130)$, group $7(0.331 \mu \mathrm{m}+/-0.063)$, group $1(0.334+/-0.026)$, group 5 $(0.316 \mu \mathrm{m}+/-0.036)$, and group $4(0.316 \mu \mathrm{m}+/-0.036)$.

Group 2 was significantly different from all the other groups analyzed, its values being significantly greater $(\mathrm{p}<0.05)$. Group 4, group 5, group 7, group 1, and group 3 did not have significant differences among them ( $\mathrm{p}>0.05)$. Group 3, and group 6 did not show significant differences between them $(p>0.05)$, but group 6 had significant differences regarding the rest of the groups with low $\mathrm{Ra}(\mathrm{p}<0.05)$ (Fig. 4)

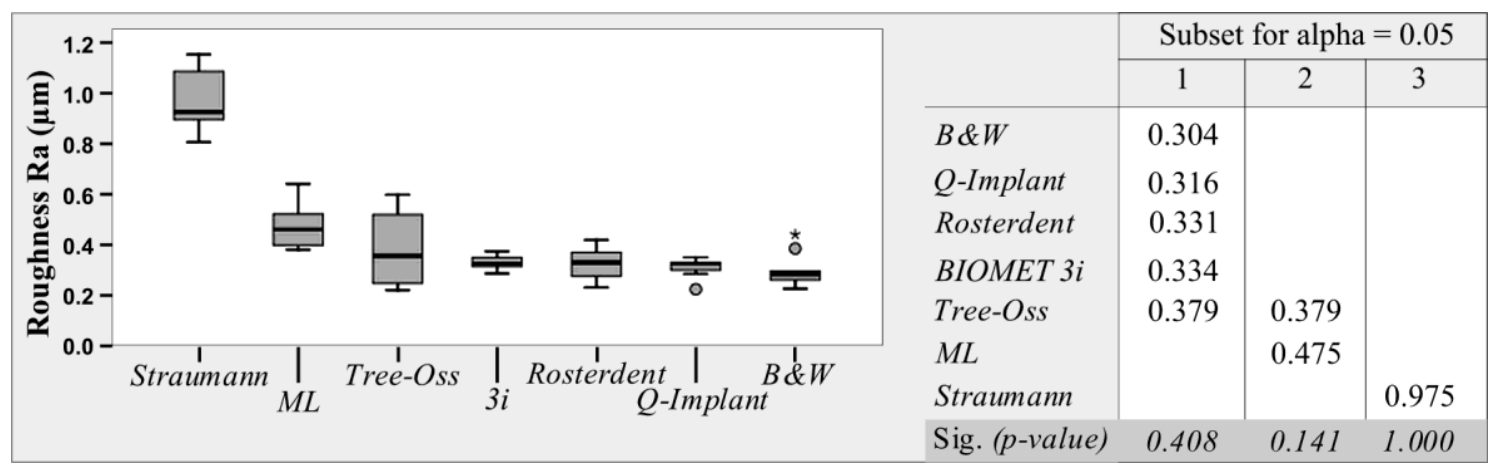

Fig. (4). Boxplot of roughness in the groups analyzed. Tukey's HSD Test showing the means for the groups in the homogeneous subsets.

\section{DISCUSSION}

One of the first strategies to improve osseointegration consisted in making the implant surface rougher. Since 1980's, implant manufacturers have developed various techniques to create roughness on the surfaces, such as titanium plasma spray or double acid-etching. The surface treated with double-acid etching presents a two-level topography consisting of $1-3 \mu \mathrm{m}$ peaks in height superimposed onto slightly rough surfaces [13].

In the early 1990's, Albrektsson T. et al. stated that a moderately roughened implant surface is favorable for implant integration to tissue. However, they reported problems with the methods used to identify an ideal topography on the surface [14]. Various studies [15, 16] have demonstrated that a low value of surface roughness promotes the formation of fibers around the implant, creating a smaller area of bone-implant contact in comparison with surfaces presenting greater roughness. On the contrary, roughness having a Ra of a micrometer or more, such as double-etched implants, enhances bone adhesion to the implant surface, allows for better retention and contact of the bone cells to the implant, and presents greater homogeneity than etched surfaces [17]. In this study, the average roughness values reached in Straumann and Biomet implants had a Ra of about $0.975 \mu \mathrm{m}$ and $0.334 \mu \mathrm{m}$, in contrast with the values published by Orsini $\mathrm{G}$ et al. In addition, in the present work implant surfaces manufactured in Argentina were studied under the same 
conditions. The roughness values obtained were $0.475 \mu \mathrm{m}$ for ML implants, 0.379 for Tree-Oss implants, 0.331 for Rosterdent implants, 0.316 for Q-Implant implants and 0.304 for B\&W implants.

In 1998, Wennerberg A. et al. published a study in which they compared machined surfaces and sandblasted surfaces. In the histological studies of sandblasted implant surfaces, the authors found a greater amount of contact bone when compared with machined implant surfaces [18]. In another study, Wennerberg compared machined surfaces with sandblasted surfaces, their roughness varying between 1.16 microns and 1.94 microns. He obtained more bone in contact with the surface in the sandblasted implants [19]. Rodriguez Rius D. et al. concluded that in order to obtain high osseointegration values. The surface roughness of titanium implants may be enhanced with chemical attacks to the implant surface [20].

In studies in dogs, Abrahamsson I. et al. demonstrated that double-etched surface implants present more contact between the bone and the implant when compared with machined surfaces [21]. Topographic modifications on titanium implant surfaces has been the object of a large number of investigations with the purpose of enhancing osseointegration, acting directly on cell adhesion, proliferation and differentiation produced during this process. Dental implants with different surface treatments are currently marketed; however, the literature reports dissimilar results regarding findings. Topography, a group of features of the surface, its roughness and chemical composition has great incidence in the longterm success on the stability of the implant as well as on the reduction of healing time and prosthetic activation of the implants.

With regard to the moment of prosthetic loading of the implants and ultra microporous surfaces, studies published by Ibañez J. et al. showed a success rate of $99.42 \%$ with double-etched surface implants in protocols of immediate loading with full arch-fixed restorations [22]. The same group published that surfaces improved with double-acid etching allow for opting between one- or two- stage surgical procedures, depending on each particular case, with similar results [23].

In a histomorphometric study of retrieved, clinically stable implants submitted to immediate loading, Romanos G. et al. stated that immediate occlusal loading may present a high level of bone-implant contact to ultramicroporous surfaces [24]. Likewise, Trisi P. et al. published histomorphological results in which they showed that there was enough bone in implants with double- acid-etched surfaces [25]. Salvi G. et al. published clinical results of implants with SLA surfaces loaded two weeks after surgery. They reported that activation of these implants did not jeopardize the healing process of osseointegration in the posterior mandible and concluded that microtopographic configurations of the implant surfaces are a major factor for determining the waiting time of prosthetic loading [26]. Acceleration of osseointegration to the implant tissues is favored in ultramicroporous surfaces. Trisi P. et al. confirmed that ultramicroporous surfaces allow contact osteogenesis phenomena when compared with machined surfaces. Therefore, Osseotite surface seems to exert a positive effect upon the amount of bone close to the implant surface [5]. In agreement with this idea, in an in-vitro study Park J. et al. investigated the influence of microrough surface on the early interactions of blood cells and concluded that double-acid etched surfaces may play an important role in the osteoconduction phases of the healing response [4]. In an experimental study in dogs, Abrahamsson I. et al also evaluated different implant surfaces and cell responses during the healing processes, reabsortive, appositional events and the quantity of bone tissue formed. They also stated that double-acid etched surfaces presented more newly-formed bone tissue than machined surfaces [6]. Likewise, by histological analysis, Lazzara R. et al. showed that the percentage values of bone to implant contact are greater in implants with ultramicroporous surface than in implants with machined surfaces [7]. In addition, Veis A. et al. presented a study in which they histologically evaluated the percentage of bone to implant contact (BIC) between machined surfaces and double-acid etched surface (Ossseotite), and in autogenous bone graft. They found that the BIC percentage in the Osseotite surface was significantly higher than that in the machined surface. Furthermore, they concluded that the use of autogenous bone graft resulted in significantly higher percentage BIC values in the regenerated area than in the basal bone area itself, for both implant surfaces [27].

Zetterqvist L. et al. showed that double-acid etched implants neither affect the health mucosa negatively nor increase the risk of periimplantitis. They also stated that microporous surface at gingival tissue level is essential to maintain long-term soft tissue stability and esthetics results [28].

Juodzbalys L. et al. demonstrated that accurate selection of the acid and the sequence of the industrial processing play a major role in raw titanium preparation. They found that the surface was less microrough if submitted to singleacid etching with chloridric acid or with sulphuric acid. They obtained similar results in processed implants mixing chloridric acid and phosphoric acid; however, the double etching process using sulphuric acid and chloridric acid in 
sequence and in a definite time showed the best results. Said investigators obtained roughness values of 0.54 in the flanks of osseotite surfaces and of 1.23 in SLA surfaces, as compared with the values obtained in the present study which were $0.334 \mathrm{um}$ and 0.975 respectively [29]. In addition, another modification in the surfaces refers to hydrophilic properties. Klein M. et al., showed their findings on SLA and active SLA, which confirmed that the combination of microroughness and high hydrophilicity clearly promotes potential osteogenic differentiation [30].

In the present study, surface microtopography determination was described by measuring the average diameter of pores in micrometers and the number of pores by $\mathrm{mm}^{2}$ found in each one of the groups studied. The values and micrometric and submicrometric topographic features obtained from Osseotite surface, Biomet 3i implant and Straumann SLA implant surface are consistent with the literature consulted. It was not possible to conduct a comparative study on the number of pores due to the fact that no research works have been carried out using a methodology similar to the one described in the present work. The selection of an implant surface designed with various topographic levels and characteristics is of great importance in order to favor osseointegration, to preserve the crestal bone and reduce its loss, to offer a good level of protection against the development of per-implantitis and to allow the acceleration of prosthetic loading times.

\section{CONCLUSION}

Surface micro topography in the different groups of dental implants studied exhibited dissimilar characteristics. Differences were found in all the groups when pore diameters were measured; Q implant showed the largest diameter and Rosterdent the smallest pore diameter. Concerning the number of pores, 3i, Straumann and Rosterdent implants presented the greatest number. With regard to mean roughness, Straumann and ML implants showed the greatest values. Superficial micro topography is one of the factors with influence in the achievement of adequate osseointegration. Its detailed knowledge is essential to implants' selection, thus obtaining predictable results. Subsequent studies on experimental animal models will be required for further appraisal of biological behavior in response to different implant surfaces and bone tissue.

\section{CONFLICT OF INTEREST}

The authors confirm that this article content has no conflict of interest.

\section{ACKNOWLEDGEMENTS}

Declared none.

\section{REFERENCES}

[1] Albrektsson T, Brånemark PI, Hansson HA, Lindström J. Osseointegrated titanium implants. Requirements for ensuring a long-lasting, direct bone-to-implant anchorage in man. Acta Orthop Scand 1981; 52(2): 155-70.

[http://dx.doi.org/10.3109/17453678108991776] [PMID: 7246093]

[2] Lazzara R. Dental implant system design and potential impact on the establishment and sustainability of aesthetics J Impl Reconstruct Dent Edit 2012; 19: 117-29. Available from: http://www.biomet3i.com/Resource\%20Center/Clinical\%20Information/JIRD\%20Editorial $\% 20$ Implants $\% 20$ System $\% 20$ Design $\% 20$ and $\% 20$ Its $\% 20$ Potential $\% 20$ Impact $\% 20$ on $\% 20$ the $\% 20$ Establishment $\% 20$ and $\% 20$ Sustainability $\% 20$ of\%20Aesthetics_ART1185.pdf

[3] Davies JE. Understanding peri-implant endosseous healing. J Dent Educ 2003; 67(8): 932-49. [PMID: 12959168]

[4] Park JY, Davies JE. Red blood cell and platelet interactions with titanium implant surfaces. Clin Oral Implants Res 2000; 11(6): 530-9. [http://dx.doi.org/10.1034/j.1600-0501.2000.011006530.x] [PMID: 11168246]

[5] Trisi P, Lazzara R, Rao W, Rebaudi A. Bone-implant contact and bone quality: evaluation of expected and actual bone contact on machined and osseotite implant surfaces. Int J Periodontics Restorative Dent 2002; 22(6): 535-45. [PMID: 12516825]

[6] Abrahamsson I, Berglundh T, Linder E, Lang NP, Lindhe J. Early bone formation adjacent to rough and turned endosseous implant surfaces. An experimental study in the dog. Clin Oral Implants Res 2004; 15(4): 381-92. [http://dx.doi.org/10.1111/j.1600-0501.2004.01082.x] [PMID: 15248872]

[7] Lazzara RJ, Testori T, Trisi P, Porter SS, Weinstein RL. A human histologic analysis of osseotite and machined surfaces using implants with 2 opposing surfaces. Int J Periodontics Restorative Dent 1999; 19(2): 117-29. [PMID: 10635177]

[8] Buser D, Schenk RK, Steinemann S, Fiorellini JP, Fox CH, Stich H. Influence of surface characteristics on bone integration of titanium implants. A histomorphometric study in miniature pigs. J Biomed Mater Res 1991; 25(7): 889-902. 
[http://dx.doi.org/10.1002/jbm.820250708] [PMID: 1918105]

[9] Wennerberg A, Albrektsson T, Lindhe J. Surface topography of titanium implants. In: Lindhe J, Ed. Clinical Periodontology and Dental Implantology. Buenos Aires: Panamericana Publishing 2005; pp. 858-65.

[10] Goldstein J, Newbury D, Echlin P, et al. Electron Microscopy and X-Ray Microanalysis. $2^{\text {nd }}$ ed. New York, London: Scanning Plenum Press 1992. [http://dx.doi.org/10.1007/978-1-4613-0491-3]

[11] Joy D, Romig A Jr, Goldstein J. Principles of Analytical Electron Microscopy. New York, London: Plenum Press 1989.

[12] Reimer L. Scanning Electron Microscopy-Physics and Image formation and microanalysis. Springer Series in Optical Sciences. SpringerVerlag Berlin Heidelberg 1985.

[13] Svanborg LM, Andersson M, Wennerberg A. Surface characterization of commercial oral implants on the nanometer level. J Biomed Mater Res B Appl Biomater 2010; 92(2): 462-9. [PMID: 19957360]

[14] Albrektsson T, Zarb GA. Current interpretations of the osseointegrated response: clinical significance. Int J Prosthodont 1993; 6(2): 95-105. [PMID: 8329101]

[15] Buser D, Schenk RK, Steinemann S, Fiorellini JP, Fox CH, Stich H. Influence of surface characteristics on bone integration of titanium implants. A histomorphometric study in miniature pigs. J Biomed Mater Res 1991; 25(7): 889-902. [http://dx.doi.org/10.1002/jbm.820250708] [PMID: 1918105]

[16] Wennerberg A, Albrektsson T, Andersson B, Krol JJ. A histomorphometric and removal torque study of screw-shaped titanium implants with three different surface topographies. Clin Oral Implants Res 1995; 6(1): 24-30. [http://dx.doi.org/10.1034/j.1600-0501.1995.060103.x] [PMID: 7669864]

[17] Orsini G, Assenza B, Scarano A, Piattelli M, Piattelli A. Surface analysis of machined versus sandblasted and acid-etched titanium implants. Int J Oral Maxillofac Implants 2000; 15(6): 779-84. [PMID: 11151575]

[18] Wennerberg A, Hallgren C, Johansson C, Danelli S. A histomorphometric evaluation of screw-shaped implants each prepared with two surface roughnesses. Clin Oral Implants Res 1998; 9(1): 11-9. [http://dx.doi.org/10.1034/j.1600-0501.1998.090102.x] [PMID: 9590940]

[19] Wennerberg A, Ektessabi A, Albrektsson T, Johansson C, Andersson B. A 1-year follow-up of implants of differing surface roughness placed in rabbit bone. Int J Oral Maxillofac Implants 1997; 12(4): 486-94. [PMID: 9274077]

[20] Rodríguez Rius D, García Saban J. Caracterización físico-química de la superficie de 9 implantes dentales con 3 distintos tratamientos de superficie. Med Oral Patol Oral Cir Bucal 2005; 10: 58-65.

[21] Abrahamsson I, Zitzmann NU, Berglundh T, Wennerberg A, Lindhe J. Bone and soft tissue integration to titanium implants with different surface topography: an experimental study in the dog. Int J Oral Maxillofac Implants 2001; 16(3): 323-32. [PMID: 11432652]

[22] Ibañez JC, Tahhan MJ, Zamar JA, et al. Immediate occlusal loading of double acid-etched surface titanium implants in 41 consecutive fullarch cases in the mandible and maxilla: 6- to 74-month results. J Periodontol 2005; 76(11): 1972-81. [http://dx.doi.org/10.1902/jop.2005.76.11.1972] [PMID: 16274318]

[23] Ibañez JC, Tahhan MJ, Zamar JA. Performance of double acid-etched surface external hex titanium implants in relation to one- and two-stage surgical procedures. J Periodontol 2003; 74(11): 1575-81. [http://dx.doi.org/10.1902/jop.2003.74.11.1575] [PMID: 14682653]

[24] Romanos GE, Testori T, Degidi M, Piattelli A. Histologic and histomorphometric findings from retrieved, immediately occlusally loaded implants in humans. J Periodontol 2005; 76(11): 1823-32.

[http://dx.doi.org/10.1902/jop.2005.76.11.1823] [PMID: 16274300]

[25] Trisi P, Lazzara R, Rebaudi A, Rao W, Testori T, Porter SS. Bone-implant contact on machined and dual acid-etched surfaces after 2 months of healing in the human maxilla. J Periodontol 2003; 74(7): 945-56. [http://dx.doi.org/10.1902/jop.2003.74.7.945] [PMID: 12931756]

[26] Salvi GE, Gallini G, Lang NP. Early loading (2 or 6 weeks) of sandblasted and acid-etched (SLA) ITI implants in the posterior mandible. A 1year randomized controlled clinical trial. Clin Oral Implants Res 2004; 15(2): 142-9. [http://dx.doi.org/10.1111/j.1600-0501.2004.01014.x] [PMID: 15008926]

[27] Veis A, Trisi P, Tsirlis A, et al. Osseointegration of Osseotite and machined-surfaced titanium in autogenous bone graft: a histologic and histometric study in dogs. Clin Oral Implants Res 2004; 15: 54-61. [http://dx.doi.org/10.1111/j.1600-0501.2004.01004.x] [PMID: 14731177]

[28] Zetterqvist L, Feldman S, Rotter B, et al. A prospective, multicenter, randomized-controlled 5-year study of hybrid and fully etched implants for the incidence of peri-implantitis. J Periodontol 2010; 81(4): 493-501. [http://dx.doi.org/10.1902/jop.2009.090492] [PMID: 20367092]

[29] Juodzbalys G, Sapragoniene M, Wennerberg A. New Acid Etched Titanium Dental Implant Surface. Stomatologija. Baltic Dental Maxillofac J 2003; 5: 101-5. 
[30] Klein MO, Bijelic A, Toyoshima T, et al. Long-term response of osteogenic cells on micron and submicron-scale-structured hydrophilic titanium surfaces: sequence of cell proliferation and cell differentiation. Clin Oral Implants Res 2010; 21(6): 642-9. [http://dx.doi.org/10.1111/j.1600-0501.2009.01883.x] [PMID: 20666791]

(c) Sezin et al.; Licensee Bentham Open.

This is an open access article licensed under the terms of the Creative Commons Attribution-Non-Commercial 4.0 International Public License (CC BY-NC 4.0) (https://creativecommons.org/licenses/by-nc/4.0/legalcode), which permits unrestricted, non-commercial use, distribution and reproduction in any medium, provided the work is properly cited. 